\title{
Moral Education and Ideology: The Revival of Confucian Values and the Harmonious Shaping of the New Chinese Man
}

\author{
Selusi AMBROGIO*
}

\begin{abstract}
In this paper, we will investigate the re-emergence of Confucianism in contemporary China as a complex intersection of political, cultural, educational and popular perspectives. This resurgence is neither a kind of Chinese Neoclassicism nor a nostalgic backwardness, instead it is the emblem of the new China's identity. Confucius and Confucianism, violently despised as the remains of feudalism since the May Fourth Movement and during Maoism, are nowadays a fertile source for the fulfilment of "Socialism with Chinese characteristics” (zhongguo tese shehui zhuyi 中国特色社会主义) on both the educational and political levels. We carry out the investigation in three steps: 1 . The political rehabilitation of Confucianism as part of the “Chinese dream" (zhongguo meng 中国梦); 2. The common social perception of Confucianism and tradition as a shared and unavoidable background; 3. The definition of two possible Confucianisms (namely New Confucianism and Political Confucianism) and their possible influences on Chinese society and moral education. Our conclusions will deal with Chinese cultural soft power, and the shaping of a new Confucian identity based on both modernity and tradition.
\end{abstract}

Keywords: political Confucianism, new Confucianism, Chinese dream, moral education

\section{Moralna izobrazba in ideologija: preporod konfucianističnih vrednot in har- monično oblikovanje novega kitajskega človeka}

\section{Izvleček}

$\mathrm{V}$ tem članku bomo raziskovali ponovno pojavljanje konfucianizma v sodobni Kitajski kot kompleksnem križišču političnih, kulturnih, izobraževalnih in popularnih perspektiv. Tovrstno oživljanje ni vrsta novega kitajskega neoklasicizma ne nostalgično pogledovanje nazaj, ampak predstavlja simbol nove kitajske identitete. Konfucij in konfucianizem, ki so ju na silo prezirali kot ostanek fevdalizma vse od Gibanja četrtega maja in tudi med maoizmom, sta danes plodna vira za izpopolnjevanje »socializma s kitajskimi značilnostmi« (zhongguo tese shehui zhuyi 中国特色社会主义), tako na izobraževalni kot na politični ravni. Raziskavo izvajamo v teh korakih: 1 . Politična rehabilitacija konfucianizma kot del

Selusi Ambrogio, Professor in Chinese Studies,

University of Macerata, Italy.

aselusi[at]yahoo.it

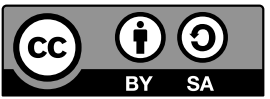


»kitajskih sanj« (zhongguo meng 中国梦); 2. Skupno družbeno dojemanje konfucianizma in tradicije kot skupno in neizogibno ozadje; 3. Definicije dveh mogočih konfucianizmov (t. i. novi konfucianizem in politični konfucianizem) in novih mogočih vplivov na kitajsko družbo in moralno izobrazbo. Zaključki se ukvarjajo s kitajsko »mehko močjo« in oblikovanjem nove kitajske identitete, ki temeljita na modernosti in tradiciji.

Ključne besede: politični konfucianizem, novi konfucianizem, kitajske sanje, moralna izobrazba

\section{Politics and the Confucian Chinese Dream}

On February 7, 2014, President Xi Jinping, commenting on the decisions of the Third Plenary Session of the 18th CPC Central Committee, explained that a new “Socialism with Chinese Characteristics" (zhongguo tese shehui zhuyi 中国特 色社会主义) meant a complete revival or rejuvenation (fuxing 复兴) of Chinese society and policy through traditional culture. He stated that:

since the introduction of the reform and opening-up policy some three decades ago, our Party has begun to ponder the issue of the national governance system from a new perspective, [...]. Today, we are tasked with an important historic mission, that is to make our socialist system with Chinese characteristics more mature and better established, and provide a more complete, more stable and more effective system for the development of the Party and the nation, the well-being of the people, social harmony and stability, and the enduring prosperity and stability of the country. Our governance system will become more efficient as long as we focus on improving the Party's governance capacity while raising the moral and political standards, scientific and cultural levels, and the professional abilities of officials [...]. The kind of governance system best suited for a country is determined by that country's historical heritage and cultural traditions and its level of social and economic development, and it is ultimately decided by that country's people. Our current national governance system has been developed and gradually improved over a long period of time on the basis of our storied heritage, cultural traditions, and social and economic development. [...] A nation's culture is a unique feature that distinguishes that nation from others. We should delve deeper into and better elucidate China's excellent traditional culture, and make greater efforts to creatively transform and develop traditional Chinese virtues, promoting a cultural spirit that transcends time and national boundaries, and has eternal attraction and contemporary 
value. [...] As long as the Chinese people pursue lofty virtues generation after generation our nation will be forever filled with hope. (Xi 2014a).

Xi Jinping always praises China's last thirty-five years of extraordinary development, which started when Deng Xiaoping proposed the opening of the Chinese economy and society to the world market. According to $\mathrm{Xi}$ and all the other Presidents since Deng, this was the only possible way of achieving policy reforms, economic growth and a better quality of life for all Chinese people. Xi openly stated that while in the 1980s and 1990s the priority was opening of free markets along with industrial and financial growth, in recent years the new focus has been on the shaping of a fair society, with this being achieved by: promoting culture and values, the only two weapons that can safeguard long-term growth and fight corruption. The term culture here refers to the traditional culture of Chinese history, the same tradition that was rejected by the leading thinkers of the May Forth Movement, as well as the founder of the Communist Party, Chen Duxiu. In 1916, Chen Duxiu contrasted the new ideology of independence (duli zhuyi 独立主 义) with Confucian values, and the latter were described as completely outdated and repressive, while independence was the condition of a modern economy and growth. Confucianism was thus seen as preventing the improvement of Chinese society. Further, Chen Duxiu (1916) declared that Confucius lived in a "feudal epoch", and therefore he provided only a feudalistic moral way (fengjian shidai zhi daode 封建时代之道德). This opinion of the founder of the Chinese Communist Party was shared by Mao, who used the term “feudalism” (fengjian 封建) as a label to use against enemies of the socialist project. However, the use of the terms "feudal" and "feudalism" is obviously only ideological, since in Chinese history they apply only to the Western Zhou (1066-771 BC). The correct meaning of the term fengjian 封建 is the decentralised system of government that was used during the Zhou dynasty. In the early 20th century, this same term was applied to mean the "Chinese empire" in order to fit into the Marxist social stages of development. As such, how could it be that $\mathrm{Xi}$ Jinping, and before him $\mathrm{Hu}$ Jintao, were so clearly working to recover the Chinese tradition of Confucianism, which is nowadays often improperly labelled as "feudalistic"?

We can find a clear answer to this question in Hu Jintao's speech at the 90th Anniversary of the founding of CPC on July 1, 2011. Hu devoted part of his long speech to an outline of the last two centuries of Chinese history and, without plainly disavowing the fact that imperialistic China was "feudalistic", he attributed the reasons for these "feudalistic" conditions to the Opium Wars and the arrogance of foreign powers, reshaping the Marxist concept as it had been applied to China. This external corruption caused the ruin of Chinese civilisation, the 
suffering of the Chinese poor, and the development of corruption. At that time, using Hu's words, "China gradually became a semi-colony and semi-feudalistic society (zhongguo zhubu chengrwei ban zhimindi ban fengjian shehui 中国逐步成为 半殖民地半封建社会)” (Hu 2011). To fight this imported corruption was thus the primary mission of the Communist Party, and it worked on this aim until the complete defeat of Japanese Imperialism and the "reactionaries" of the Guomindang in 1949. According to $\mathrm{Hu}$, what followed was the creation of a socialist society under Mao, but the real success was the third phase, when China undertook the process of reform and economic opening with Deng Xiaoping, finally creating a socialistic society with Chinese characteristics. This is a Chinese Socialism that needs, in order to be truly Chinese, not only economic growth but, first of all, Chinese culture, literature, tradition and wisdom, which are no longer seen as "feudalistic relics".

This is the reason why Xi Jinping set out the idea of the "Chinese dream" (zhongguo meng 中国梦) as the goal of his mandate, a dream of prosperity and harmony that necessarily needs Chinese traditions, values and the close study of ancient texts. In a speech on October 21, 2013, the Chinese President gave example of some exemplary students: Confucius, Sun Jing, Su Qin, Kuang Heng, Chen Yi and Sun Kang, the six leading figures of classical Chinese Confucianism, and even quoted Mozis "exaltation of the virtuous is fundamental to governance" (Xi 2013a). Again, on June 6, 2014, while speaking to Overseas Chinese Associations, he highlighted the role of culture and tradition as the common link among all Chinese, and therefore as the real Chinese identity, which is shared, we can guess, even by those who left China before 1949. Here, Xi said:

For Chinese people both at home and abroad, a united Chinese nation is our shared root, the profound Chinese culture is our shared soul, and the rejuvenation of the Chinese nation is our shared dream. [...] Chinese civilization, with a history going back more than 5,000 years, provides strong intellectual support for the country's ceaseless self-improvement and growth. No matter where a Chinese is, he always bears the distinctive brand of the Chinese culture, which is the common heritage of all the sons and daughters of China. I hope all Chinese will continue to carry forward Chinese culture and draw strength from it, while promoting exchanges between Chinese civilizations and other civilizations. Let us tell the stories of China well, and make our voices heard [...] (Xi 2014b)

In this excerpt from Xi's speech, Chinese tradition is presented not only as Chinese heritage, as the links among a dispersed and fragmented civilisation, but also 
as a universal philosophy, able to attract people from different countries and civilisations. As such, all other civilisations have to respect and take into consideration this thousands-year old tradition, full of wisdom and moral probity. Therefore, both within and outside China, tradition was set up the central tenet of the new policy. Within the country it provides the backbone of society and the means for the process of moralisation at all levels, while outside it is the presentable and attractive face of the nation, which grants stable international relationships and equal cultural exchanges. Tradition is thus the emblem of China's soft power (Scarpari 2015), as Xi Jinping noted on December 30, 2013:

The strengthening of our cultural soft power is decisive for China to reach the Two Centenary Goals and realize the Chinese dream of rejuvenation of the Chinese nation. [...] To strengthen our cultural soft power, we should disseminate the values of modern China. During its 5,000year history, the Chinese nation has created a brilliant and profound culture. We should disseminate the most fundamental Chinese culture in a popular way to attract more people to participate in it, matching modern culture and society. We should popularize our cultural spirit across countries as well as across time and space, with contemporary values and the eternal charm of Chinese culture, which feature both excellent tradition and modern spirit, both nationally and internationally. (Xi 2013b)

We thus see, at least in these Presidents' speeches, the growing interest in Chinese tradition within the political elite, and as a real asset of Chinese policy. Chinese Presidents clearly understood that in order to compete with the USA and Europe, the country needs not only a strong economy and stable market, but also competitive scientific culture and broad cultural appeal. The "Chinese dream" thus needs to look backward in order to look forwards.

\section{Confucianism as a Contemporary Social Asset}

Now we should try to understand whether this use of traditional culture was just a political campaign led by the last two Presidents, or instead the expression of a mass phenomenon already rooted in society. The answer is not simple, but we can simply say that in this regard the Communist Party is meeting a social demand for the rehabilitation of tradition, since traditional culture-despite almost a century of condemnation-never really disappeared among the common people. We can find support for this incontrovertible fact in several ways, and one of the best is to consult a few recent surveys on social perceptions of cultural values. 
Between January 1, 2012 and December 31, 2014, the website zhongguo zhengzhi zuobiaoxi 中国政治坐标系 (The Chinese Political Compass) conducted a large survey with fifty questions, which included items on national and international politics, micro and macro-economy, security, culture and society. Over those two years there were more than 460,000 online responses, with the possible answers to the related statements being: strongly disagree, disagree, agree and strongly agree. Of the fifty questions, the following five are of great interest to our investigation: 42. "One should not openly comment on the shortcomings of our elders" (bu ying kai tanlun ziji zhangbei de quedian 不应公开谈论自己长辈的缺点); 43. “Modern Chinese society needs Confucianism" (xiandai zhongguo shehui xuyao rujia sixiang 现代中国社会需要儒家思想); 46. “The eight diagrams of The Book of Changes can explain many facts" (zhouyi bagua nengguo youxiao de jieshi henduo shiqing 周 易八卦能够有效的解释很多事情); 47. “The perspective of traditional Chinese medicine on human health is superior to that of modern mainstream medical science" (zhongguo chuantong yixue dui renti jiankang de guannian bi xiandai zhuliu yixue geng gaoming 中国传统医学对人体健康的观念比现代主流医学更高 明); 49. “Traditional Chinese classics should be the basic education material for children" (yingdang zhongguo chanting wenhua de jingdian zuopin wei ertong jichu jiaoyu duwu 应当将中国传统文化的经典作品为儿童基础教育读物).

Question n. 42 raises the central tenet of Chinese traditional society as based on social rites ( $l i$ 礼), namely xiao 孝, that is usually translated in English as filial piety and states the unconditional love and respect of children for their parents. In the Analects 4.18 Confucius says: "In serving your father and mother, remonstrate with them gently. On seeing that they do not heed your suggestions, remain respectful and do not act contrary. Although concerned, voice no resentment”(Ames and Rosemont 1998), 子曰: 「事父母幾諫。見志不從, 又敬不 違, 勞而不怨。」. Confucius is thus suggesting that children should never act against their parents, even if they seem to be at fault. The Chinese respondents were almost equally divided, with 7.3\% strongly disagreed, 38\% disagreed, 34.8\% agreed and $19.9 \%$ strongly agreed. In short, $45.3 \%$ of them disagreed while $54.7 \%$ agreed, suggesting the endurance of classical Chinese social values even among internet users aged mostly between 18 and 30 .

On the relevance of Confucianism (n. 43), the vast majority disagreed (73.4\%), however this negative answer is counterintuitive, since filial piety, rituals, and etiquette are the core of Confucian thought. Therefore, according to this survey, Confucianism in China still suffers from a negative image, but as an institution of power and not as a social norm or form education. We will return to this point later (see 4. Conclusions). 
Question n. 46 is about one of the most famous books of Chinese wisdom, The Book of Changes (Yijing 易经 or Zhou Yi 周易). The eight diagrams are the base of the sixty-four hexagrams that are used to predict and explain events, and to understand the deep nature of each person. These diagrams were seen as ineffective by $47.7 \%$ of the respondents, while effective for $52.3 \%$ of them. Again, as for filial piety, for this item a slight majority of the respondents seemed to defend traditional culture.

However, the most surprising data are related to the last two questions. Question n. 47 , on the validity of Chinese medicine, received $64.3 \%$ positive answers, indicating that most respondents felt that this approach to the human body and health was superior to modern, mainstream medicine. Similarly, $62.1 \%$ of the respondents agreed with the use of Chinese classics as core texts for children in school (n. 49), or to be more accurate only 3.9\% strongly disagreed, 33.9\% disagreed, $51.2 \%$ agreed and $10.9 \%$ strongly agreed. 经典 (Classics) is a general term meaning many different ancient works, but among them we could mention the Five Classics (wujing 五经), namely The Book of Documents (Shujing 书经), The Book of Poetry (Shijing 诗经), The Classics of Rites (Liji 礼记), The Book of Changes (Yijing 易经), The Spring and Autumn Annals (Chunqiu 春秋) and, the four Confucian Books (sishu 四书), including The Analects (Lunyu 论语) by Confucius and Mencius (Mengzi 孟子). In our opinion, comparing the answers to questions n. 43 and n. 49 we find a clear incongruity, since Confucianism was seen as unnecessary for a large majority of the respondents, but the Classics, which were largely shaped and influenced by Confucianism (sishu wujing 四书五经), are suitable as a basis for children's education. We thus suggest that Confucianism as a political institution is being rejected, while Confucianism as a moral practice and as a social regulator is still appreciated by a large number of Chinese people.

S. Billioud and J. Thoraval (2014), have recently shown that since the year 2000 a clear Confucian renewal has taken place in three areas: 1 . In education, with the creation of the Confucian scholastic academies (sishu 私塾); 2. In the religious or spiritual area, with the growing relevance of traditional ritualism, with rites of passage and celebrations in honour of Confucius, particularly in his hometown Qufu; and 3. Confucianism as moral path or rendao 人道 for all Chinese people. The two authors, at the end of their comprehensive investigation, suggest that we are facing two kinds of Confucianism: a popular one, active in Chinese villages and among humble people living traditional rural lives; and an elitist one, in order to educate a new political class. We clearly see the double concern of modern Confucianism here: the growth of popular consent, and the active role of a new elite in the socio-political future of the country. In this context tradition is not to be seen as something confined to isolated rural backwardness, but rather the 
future of one of the most powerful nations in the world. As we have seen in previous paragraphs, Chinese traditions and Confucianism are the core of the "Chinese dream" launched by Xi Jinping.

Connected with the issues of "popular Confucianism" and a "Confucian elite", Shi Tianjian (2015) suggests, through the use of several thorough surveys, that we can find two kinds of democratic orientations among modern Chinese people: 1. Idiocentric, namely a policy theory centred on individuals; and 2. Allocentric, where social relationships, communitarian life and relational values are the real core. The allocentric democratic orientation is very diffused in China, and traces its origins back to Confucius himself, as, in The Analects 2.3 he teaches: "Lead the people with administrative injunctions and keep them orderly with penal law, and they will avoid punishments but will be without a sense of shame (chi 恥). Lead them with moral excellence and keep them orderly through observing ritual propriety and they will develop a sense of shame, and moreover, will order themselves" (Ames and Rosemont 1998), 子曰: 「道之以政, 齊之以刑, 民免而 無恥; 道之以德, 齊之以禮, 有恥且格。」. Confucius thus bases his system on the sense of shame ( $c h i$ 耽/耻), and so the social burden of admonition and punishment is displaced from a central governmental authority to society itself, and particularly to the family. This leads to a collective society where the allocentric orientation is more natural, while the idiocentric is in complete contrast with tradition and culture, perceived as an imported Western ideology, mostly diffused in large cities and coastal provinces — as the study by J. Pan and Xu Yiqing (2015) has also shown about the diffusion of more liberal ideas.

Contemporary China is searching for its "Chinese socialist way" within a renovated "allocentric" orientation that has Confucianism as driver and champion. However, this rich vein of morality and wisdom is not univocal, since in the last century Confucianism underwent several important changes and alterations. Therefore, we have to try to investigate which Confucianism can be dreamt within the "Chinese dream" (zhongguo meng 中国梦), and which can be proposed as the basis of a new "Confucian education".

\section{The Two Approaches to Confucianism: Political or Personal Education?}

In 1911 the Chinese Empire collapsed together with all the institutions based on Confucian tradition: the Imperial Examinations (which had already ended in 1905), the Imperial Hanlin Academy, the rituals performed by the Imperial Court, the temples and so on. The May Fourth Movement and the Communist party fought against any traces of Confucianism and other traditional values. However, 
within the recently founded Chinese universities, traditional values found strong supporters in the fields of philosophy and classical studies. When the Communist Republic was established 1949, the majority of intellectuals left China for Taiwan, Hong Kong and even western countries, such as the USA, the UK, or France.

\section{New Confucianism}

Among those intellectuals there was the philosophical school of New Confucianism, with Xiong Shili, Mou Zongsan and Tang Junyi as leading thinkers. New Confucianism xinrujia 新儒家 is not a recent phenomenon: rather it is rooted in the thought of the Song Dynasty (960-1279), when Confucian thinkers, influenced by the Buddhist universal metaphysics of the "Buddha nature" foxing 佛 性 in all men, started to present good human nature shanxing 善性 as universal and common to all beings. Therefore, since this time Confucian philosophy has shown more abstract and metaphysical concerns as compared with the practical political interests of Confucius or Mencius. Obviously, "practical or political Confucianism" never disappeared from Chinese society, Confucianism being the institutional foundations of the Imperial system. However, when in 1911 the Empire collapsed, Institutional Confucianism lost not only Imperial support, but also its reason for being. That is why, even in Taiwan or Hong Kong, where the societies guarded its traditional aspects, Institutional Confucianism often lost its place to the metaphysical New Confucian philosophy that bloomed in the 1960s and 1970s, particularly within the international cross-cultural academic milieu.

But we now need to bear in mind that in the mid-19th century, when the military and economic power of the Empire showed all its weaknesses in the Opium Wars and the Taiping Revolution, a four-character expression circulated among learned Chinese men: zhong ti xi yong 中体西用, which we can translate as "Chinese [culture] is essence, while Western [knowledge or science] is function". The idea was that Western military capacity and scientific knowledge were indisputably superior to those of the Chinese, but these abilities were only devoted to practical ends, and the continuous evolution of techniques and knowledge within China would make this superiority unstable and temporary. On the opposite side, Chinese traditional wisdom of self-cultivation and moral norms were the unchangeable structure of society, and went straight to the core of an unalterable human nature. The author who diffused this sentence was the eminent Qing official Zhang Zhidong, who explained, in his Exhortation to Study (Quanxue pian 劝学篇), the necessity of both science and morality (Zhang 1998). The Confucian reformers of the last decades of the Qing Empire, such as Kang Youwei, tried to use this 
concept of "Chinese culture as structure" (zhong $t i$ 中体) as a basis for the reform of Chinese society, but their attempt failed, being repressed by court conservatism. After 1911 this programmatic proposition was gradually dismissed and lost its social appeal under the attack of both modernism and New Confucianism.

As we said above, Confucianism survived as a system of thought among those philosophers who mostly belonged to the school of Modern New Confucianism xiandai xinrujia 现代新儒家. Those thinkers were not backward traditionalists, but rather philosophers fully aware of Western philosophical thought who struggled to find and claim a place for Chinese thought within World Philosophy. They refused the zhong ti xi yong 中体西用 theory (Chinese culture as essence and Western as function), since they were trying to insert Chinese philosophy in a direct dialogue with other philosophies, and this was incompatible with the presumed superiority of Chinese wisdom. But at the same time, they were refusing the Western theory of Chinese intrinsic inferiority as advocated within the Hegelian, Positivist or Weberian schools. Their proposed systems of thought-we cannot investigate these in detail in this article-were refined adaptations of Chinese thought on human nature and human education to the language and concepts of Western humanities. For instance, Mou Zongsan proposed a critical analysis of Kantian moral thought which led to the creation of a "moral metaphysics", where we have not a metaphysics applied to morality — as in Kant-but instead a metaphysical investigation that in its doing provides a morality rooted in human nature itself. Turning Kant's system upside-down, while the latter limited man's understanding only to sensible intuition, Mou believed that man has a direct intuition of reality that derives from his human nature, and that this is shared with the whole of Nature (i.e. with all beings). According to Mou, each man is a unique “through-hole" tongkong 通孔, and "through-holes" are the only ways for truth to reveal itself to the world. We can say that men are necessary for truth. Therefore, each man, being this "through-hole", has direct access to the essence (noumenon) of reality or truth (dao 道). Humans have direct access to reality, and this is the perfect teaching of New Confucianism. Chinese philosophy is "concrete philosophy” juti de zhexue 具体的哲学 searching for a concrete universal juti de pubian 具体的普遍 truth, and not, as for Western philosophy, an abstract chouxian de 抽 象的, a truth far from human life (Mou 2009, ch. 1-2).

According to Mou, despite the greatness of this idea, China has lost its creative energy since the Qing dynasty, when Song and Ming Neo-Confucianism first started to be despised as abstract and useless thought, and under the Communist government the complete destruction of traditional culture reached its apex (ibid., ch. 19). Against this attack on the Chinese soul, in 1958 Mou Zongsan, Tang Junyi and several other leading thinkers of New Confucianism-despite 
this having never been a coherent school (Makeham 2003, part. I) - signed and diffused in the Hong Kong press their "Declaration on Behalf of Chinese Culture Respectfully Announced to the People of the World" (wei zhongguo wenhua jinggao shijie renshi xuanyan 为中国文化敬告世界人士宣言), a document that we now see as a conservative and a doomed attempt to restore Confucian thought against the ruse of Positivist Western thought and Communism. This declaration, although unfulfilled, was the first collective action of New Confucian thinkers, and in some ways shaped their identity. It was only with the opening of China, guided by Deng Xiaoping in the late 1970s, that Chinese New Confucian thinkers openly expressed their thoughts in mainland China and started to create a common identity with real affiliations among schools and subgroup branches, in order to find an orthodox thought and lineage. As noted by Makeham, we could identify at least seven characteristics shared by New Confucian thinking:

[1.] Confucianism is accepted as the orthodoxy and main pillar of Chinese culture. As a branch or school within Confucianism, the New Confucians place a high value on xin xing zhi xue 心性之學. [...2.] New Confucians regard China's historical culture as a spiritual reality (jingshen shiti 精神實體) and the flow of this historical culture is where this spiritual reality is manifest. [... 3.] New Confucians affirm the notion of daotong 道統 (interconnecting thread of the way) as the basis for nationhood and the source of cultural transformation. [... 4.] New Confucians emphasize the need to adopt a respectful and empathetic attitude to China's historical culture. [... 5.] New Confucians have a strong sense of “origin; roots (genyuan 根源)." [...6.] New Confucians evidence a keen awareness of the crisis facing Chinese culture [... 7.] New Confucianism is rich in religious sentiment and has a strong sense of mission to rejuvenate Chinese culture. (Makeham 2003, 29-30)

Obviously those seven threads are disputable, but they enrich our discussion on the contemporary "Chinese dream" and on the relevance of Confucian education to today's China. As to the first point, for New Confucianists Confucianism is the core of Chinese culture, the origin or at least the most relevant actor in establishing the Classics and the bases of Chinese traditional culture. Clearly, other schools of thought, such as Daoism, Legalism, and even Buddhism. have been relevant, however none of them could compete with the active shaping of society carried out by Confucianism, this being the leading school of thought within the Imperial Court and the Imperial Hanlin Academy. The further characteristics shared by the New Confucians, from 3 to 6, above, have to do with the mission those thinkers undertook, namely the protection of Confucian or Neo-Confucian thought 
as the well-spring of Chinese tradition and culture. But two points are much more relevant, numbers 2 and 7, which see New Confucianism, or simply Confucianism, as a religious teaching that could rejuvenate the nation. Confucianism is both a philosophical system and spiritual belief, which can enrich a soulless society. In order to understand this point, we need to look closer at what the establishment of a correct tradition meant in China. In pre-Imperial China, history was interpreted through a correlative scheme of five agents, 五行, and these are descriptive concepts that the possible configurations of $q i$ 氣, the vital energy that underlies everything in the world. This correlative scheme of five elementswood, fire, soil, metal and water - is used to understand and define everything in the world, biological life as diseases, the individual psychological dispositions as physical characteristics, the correct form of education in human life, the seasons as colours, but, most relevant for us, historical events-i.e. the collapse of dynasties and the breaking out of wars-as social relationships (Graham 1986; Graham 1989). Therefore, Confucianism as an interpreter of political and social life is the only effective way to forecast, prevent and understand events. We thus argue that this ability to penetrate the essence of $q i$, as acknowledged for Confucianism, is the reason for both the definition of Chinese culture as a "spiritual reality" (jingshen shiti 精神实体), and the central role Confucianism must have in the "revival" fuxing 复兴 of this culture. We know that the term “renaissance" is the heart of the "Chinese dream", and it is the core of a new education of Chinese society from its psychological and historical roots.

\section{Political Confucianism}

In 1983 the Confucius Foundation was set up in Beijing with the full support of Deng Xiaoping and the Communist Party, and we can see this as the starting point of Xi Jinping's "Chinese dream”. In 1989, at the 2540th anniversary of Confucius's birthday, the President of the People's Republic Jiang Zemin blessed the event, praised all the participants' speeches, noted the historical relevance of Confucius as the father of Chinese culture, and highlighted Confucius's teachings as a model of correct moral education. At this event, $\mathrm{Gu} \mathrm{Mu}$, who was Deng's right-hand man in the economic modernisation program, delivered a long speech advocating the decisive role of Confucianism in China's past, present and future. He praised Confucian values such as harmony, wisdom, social relationships, respect for authority, and complete pedagogy, as valid tools against the spiritual pollution from the West that had caused the Tiananmen demonstrations. From this moment forward, Confucianism started to be a conservative and traditional force that could be used to maintain authority. We quote just a few lines of this speech, as follows: 
The Chinese nation has had a long history and brilliant ancient culture. For a long period of time in human history, the Chinese culture, with Confucian school of thought as the mainstream, glittered with colourful splendour [...] Culture serves both as the emblem of the level of civilization of a nation or a country, and the guidance for its political and economic life. To promote prosperity and peace for a nation and for mankind in general, it is necessary to develop a compatible culture. In this regard, a proper attitude toward the traditional national culture is very important. (Gu 2000)

Reading these lines from Gu Mu's 1989 speech, it is natural to find analogies with those of Hu Jintao and Xi Jinping. Already in 1989 the new cultural course of Chinese socialism had begun. While it was not termed "socialism with Chinese characteristics", it was already allied with the conservative and nationalist forces of Chinese learned society. At this time, the Chinese Communist Party, which is considered a leftist force in the West, moved closer to the nationalist and conservative Confucian side, which in the West would be considered on the right side of the political spectrum. This is the reason for a contemporary society split in two, with the Communists and traditionalists on one side, and liberal, reformist and Westernised people on the other.

Now we understand the relevance of a correct definition of Confucianism, since it became an active force in Chinese society at both the political and social levels. Is this Confucianism the New Confucianism we just outlined, or not? Is there a different kind of Confucianism in contemporary China? The answer to both questions is positive, since we have at least one other huge theoretical Confucian school that is gradually imposing its interpretation on the old teachings. This school is usually termed "Political Confucianism" or "Institutional Confucianism", and it is headed by Jiang Qing, who in 1996 founded the Yangming Academy 阳 明精舍 in Guiyang (Guizhou), a Confucian-based academic institution that is defined in several websites as being devoted to ancient Chinese culture, being "the modern school that most aims at restoring the ancient way” (阳明精舍一最复古 的现代书院), and therefore the emblem of contemporary Confucian education.

Jiang Qing is an open enemy of Neo-Confucian and New Confucian philosophy, since he contends that the related philosophers were influenced by liberal democracy, and that their schools are not based on Confucian philosophy but on Western Kantianism and Idealism, to the point where we can find no traces of Confucian logic in their discourses. As everyone learned in Confucian philosophy since the time of Confucius should know, Confucianism is twofold, since it is devoted to the teaching of both external kingship (waiwang 外王), and internal 
wisdom (neisheng 内圣). The external kingship is an effective system, with good ruling and political institutions that include all the Confucian rites. The internal wisdom refers to the interior development of the individual, who cultivates his moral nature, educates his heart-mind (心) and achieves the final, perfect state of a wise man. After Jiang, New Confucian philosophers completely neglected the first aim of Confucian teaching, since they devoted their attention only to internal cultivation, and this is the reason for calling this school of thought "Mind Confucianism", which is the translation of xin xing ruxue 心性儒学, namely Confucianism devoted the study of the nature of the heart-mind. Jiang Qing quotes as best example of this deviation Mou Zongsan and Tang Junyi, who paid attention only to the "good life" and not "good ruling", since they implicitly supported the liberal democratic society of the West. Therefore, Jiang Qing contends that the New Confucians proposed that Chinese people should live in a Western society, where their moral and internal wisdom could find a perfect fulfilment; we can say "(ancient) Chinese within, but Western outside".

As Jiang Qing argues:

I think this contemporary neo-Confucian solution is mistaken because it treats Western democracy and science as the ultimate standard for the development of Chinese socio-political institutions, thus justifying the suspicion that it advocates a disguised version of China's Westernization rather than authentically developing Confucianism. Neo-Confucianism's solution attempts to derive Confucian socio-political institutions exclusively from the Mind Confucianism scholarship and ignores the existence of another strand of the Confucian tradition, namely, Political Confucianism, which has many resources for developing political systems. It is unfortunate that contemporary Neo-Confucians regard modern science as intrinsically valuable. Science is only instrumentally valuable. The Chinese can certainly learn from and adopt modern science in their society, but they must regulate science according to Confucian moral values. (Jiang 2011, 24).

We see in Jiang's words the concept underlying the already quoted four-character expression of the late Qing, namely "Chinese culture as essence and Western as function" zhong ti xi yong 中体西用. Science has to be studied and used, but the only standard in its use should be Confucian morality. The same goes for democracy, that it should be studied but never applied to Chinese society, since, as Jiang explains in several essays, this political system has Western roots and is linked to European religions, and furthermore, it is an imperfect system that promises but 
never really aims at achieving equality. This political system is thus unsuitable for China, and would destroy Chinese tradition and Confucianism.

Jiang Qing thus prefers the Confucian lineage of Gong Yang's (公羊) scholarship that has Xunzi-an opponent of Mencius's "good nature theory” followed by New Confucians-among its most ancient supporters. The Gong Yang school of thought was developed during the Han dynasty period (Li 2014, 243-4), and it was very influential. Afterwards, during the Song and Ming eras, it was neglected because of the power of Neo-Confucians (i.e. Mind Confucianism), and it was finally rescued by late Qing Confucians such as Kang Youwei (1858-1927). The major works of this lineage are The Book of Rites (Liji 礼记) and The Spring and Autumn Annals (Chunqiu 春秋), together with the Han dynasty commentaries (Jiang 2011, 25). Jiang Qing even reassures New Confucians when he argues that both Confucian lineages have legitimacy, but that they must converge again, together providing a teaching of external kingship (wai wang 外王) and internal wisdom (nei sheng 内圣).

Jiang Qing goes even further, proposing a modern "external kingship” or political system based on Confucian wisdom. He shapes a tricameral system as follows: 1 . “The House of Profound Confucians" (tong ru yuan 通儒院), where Confucian learned men maintain and protect the legitimacy of the sacred way (dao 道); 2. “The House of National Continuity" (guoti yuan 国体院) where deep connoisseurs of cultural heritage and tradition deliberate about ancient values; 3. "The House of Plebeians" (shumin yuan 庶民院), where common people's needs and desires are represented (Jiang 2013). The first chamber finds its legitimacy with respect for the sacred way, and thus in the spiritual or religious realm. The second chamber has legitimacy from Chinese tradition and ancient learning. The last chamber's legitimacy lies in the common people's will. Therefore, the sacred or holy, the perfect learning and the people are all represented, and each chamber has its duty and field of deliberation. This refined and complex tripartite structure reflects the ancient Chinese cosmology that combines the Sky (tian 天), Earth (di 地) and Humanity (ren 人) in one organic body. The Sky is the normative principle that regulates everything and legitimates any change; the Earth is the productive power, the feminine womb where life puts down its roots; the Humanity is the higher form of life, and has in itself a regulative role being the principal actor with regard to stability between Sky and Earth, but Humanity is also the most dangerous cause of instability.

Wang Ruichang (2011) claims that this system merges together pre-modern absolutism, because it imposes a State religion (i.e. Confucianism), and a kind of modern liberalism, because it speaks openly about people's desires and wills 
(in the last chamber). Therefore, according to Jiang, China needs to establish Confucianism as the State religion, since legitimacy, stability, correct ethics and spiritual cultivation would arise from this system. To critics who fear an intolerant society where only the belief in Confucianism would be accepted, Jiang replies that Confucianism has always been tolerant, and that the State religion would not regulate private beliefs. Anybody can thus have private religious beliefs, just like in Western countries, but this private belief - such as the Christian religion, Buddhism, etc.- - should never contend for the role of the State religion (Jiang 2013, 170-1). The same goes for any social questions, such as that of homosexuality, that, according to Jiang, should be tolerated, while everybody has to respect the Confucian social system. Nothing that diverges from stability and legitimacy would be allowed, but private life would be respected. He even speaks of a possible monarch with an ancient blood lineage from Confucius, who should have a symbolic role, like the Thai monarch, a kind of embodiment of legitimacy, a cultural and spiritual guarantor.

We see in Jiang Qing's project the clear intention to revitalise Confucianism not only at the popular level, namely as education, but also at the institutional one. While New Confucians' Confucianism is for people living in a modern political society, with modern-and likely desacralized and secular-institutions, Jiang Qing's Confucianism aims at becoming the foundation of society itself. These two ways of Confucianism could not be more different, they are the separate sides of the already quoted “inner wisdom" (nei sheng 内圣) and "outer kingship" (wai wang 外王) dichotomy. It seems impossible to bridge this gap, since they are Confucianism's two faces, but are they perhaps two faces of the same coin?

\section{Conclusions}

Now the time has come to inquire which one of these two faces shall be the Chinese Confucianism of its future political and educations systems. More correctly: which one is more compatible with $\mathrm{Xi}$ Jinping's "socialism with Chinese characteristics"?

We think there is not an unequivocal answer to these questions. What is indisputable for scholars is that New Confucianism is usually interpreted as bending to Western liberal democracy, something hardly compatible with the Chinese political system. However, since Stephen C. Angle (2012) suggests that a perfect democracy is almost impossible, and so what is possible in Chinese society is a kind of "moderate perfectionism", where the widely shared values of Confucianism are supported and protected by the State, but the majority of choices are set free. The 
values the State protects are humaneness, righteousness, propriety, wisdom and faithfulness, and thus education. In this "moderately perfected democracy", New Confucianism should establish its political party without becoming a religious teaching, but instead a pedagogical and spiritual asset. What Angle does not discuss is the feasibility of this project in a one-party political system, i.e. the role of the Communist Party. In our opinion, it is more natural that a trend within the Communist Party would gradually endorse Confucian values as a political project, and that is actually what $\mathrm{Xi}$ Jinping is suggesting without naming this project in Confucian terms.

What about Jiang Qing's three chambers? Socialist Chinese politics are laic but guarantee religious freedom. In the 1982 Constitution it is stated that "The State protects legitimate religious activities. No one may use religion to carry out counter-revolutionary activities or activities that disrupt public order, harm the health of citizens or obstruct the educational systems of the state. No religious affairs may be dominated by any foreign country." (Yoshiko and Wank 2009, 11). Chinese Constitution does not consider a State religion or even religious education to be possible, i.e. Confucian schools cannot replace national education. It is more likely that Institutional Confucianism will gradually gain more relevance, but in the given spaces guaranteed by the Chinese State. As Chau clearly explains:

There are broadly speaking two strategies which people "doing religion" in China adopt in negotiating with the party-state to attain a higher degree of legitimacy. The first is "getting into the official fold", which is to obtain the status of belonging to one of the five officially recognized religions and becoming an officially recognized "venue for religious activities". [...] The second strategy is "creative dissimulation", which is to disguise one's religious activities as something else that is more palatable in official eyes. [...] to get their deity worship or ritual practice recognized (and accredited) by the State as "intangible cultural heritage" [... (Chau 2011).

While the first strategy, to become a religious official, is suitable for Buddhism, Daoism, and Islam, and far from Jiang Qing's project, it is the second which seems more suitable for Institutional Confucianism, and in effect he has founded an academy for this in Guizhou. However, even if this is the more suitable way to become approved as "religious thought", this does not mean that it will become a "State religion", since this would seriously interfere with the Chinese political status quo. We note that since the year 2000 the question of whether Confucianism is a religion has provoked a harsh "religion debate" (Sun 2013, 82-93) that 
remains unresolved, because, as we know thanks to our analysis, the concept of "religion" is not only a cultural label, but a relevant (conservative) political asset, while traditional education seems more neutral.

As we said for New Confucian, which could be partially absorbed by the Party, the same is true for Institutional Confucianism. More than a completely new institutional configuration, a gradual alignment of some of the Party with this system is more likely. This political trend would represent all the three Chambers in itself, including experts of Confucian wisdom, traditional knowledge and the common people. As we have seen on reading $\mathrm{Hu}$ Jintao and Xi Jinping's speeches, Confucianism is already labelled as a national force, the deep roots of Chinese culture and the grounds for a Chinese future. Therefore, within the Communist Party a large percentage of leading politicians already share the project of the "Confucianisation" of society, but this does not mean they will become "Confucians" instead of "socialists". There are even several socialist thinkers who present a natural convergence between Confucian and Marxist values, since both support people's moral transformation and an "allocentric" attitude, as Shi Tianjian (2015) termed it. Moreover, Confucianism has never really been eradicated from Chinese society, and people are fond of Confucius's texts, as seen in the unpredictable success of Yu Dan's self-help book on the Analects, which has sold over ten millions copies (including six millions pirated ones), with Daniel E. Bell even suggesting a new wave of Confucianism in Chinese public schools and within the Central Party School in Beijing Bell 2010, 26, 59). However, this "wave" still does not imply that the Party is leaving behind its socialist soul, but rather that the socialist and the Confucian souls are merging together into one "Chinese soul". Confucianism guarantees all the main Chinese political characteristics: a society based on social relationships, paternalism, moralism, strong government control, limited political dissent, social harmony and so on.

Therefore, we suggest that both forms of Confucianism are suitable in the construction of China's internal and global identity. Internally, Jiang Qing's political thought would provide a strong validation for an authoritarian and stable system, where the wealth of the society as a whole is always more relevant than the wealth of its individuals. Clearly, harmony ( $h e$ 和) often means the flattening of creativity, as seen in the recent suppression of artistic freedom (Breacher 2014) and censorship (Sala 2016) demonstrate. Xi Jinping is worried by any alternative to his "socialism with Chinese characteristics", and critics are perceived as deviant actors with political motives. Suggesting a long-lasting tradition of Political Confucianism that allows limited freedom, Jiang Qing provides a cultural and identitary reason for this authoritarian system. This is why any Western claim for freedom or form of protest - within or outside China—would first be marked as 
a cultural offence. We believe that China has the right to protect its culture and social system against foreign arrogance, but that does not mean that this culture should prevent any form of dissent, as dissent has always been a key part of Chinese cultural, literacy and political tradition, such as Confucius leaving his official position, as well as the actions of $\mathrm{Qu}$ Yuan, Su Shi and many other relevant thinkers in different epochs of Chinese history.

On the other hand, the New Confucian theories of inner cultivation and moral behaviour make a great contribution to the education of a rapidly modernising society in search of identity. The contradictory results of the first survey we quoted in chapter 2 may be interpreted as being in accord with this form of Confucianism. In our opinion, the strong rejection of the usefulness of Confucianism in modern society proves the respondents' suspicions concerning applying this tradition to contemporary political thought, since they see Confucian institutions as oppressive. However, this rejection does not concern Confucianism as a way of perfection or as wisdom, since the same respondents acknowledge the relevance of the Confucian classics, Confucian moral values, Chinese education, and Chinese medicine in the shaping of Chinese identity. This means that, according to this survey and the others we quoted, Chinese society is largely compatible with New Confucianism, but less so with Institutional Confucianism. We thus suggest that the Chinese political system is likely far more attracted by a strong authoritarian Confucian identity, while Chinese modern society-mostly in the big coastal cities-would at the most accept the New Confucian form, which belongs to individuals and does not determine the shape of society. We propose the following image: Political Confucianism demands Confucianism to be the body of Chinese society, while New Confucian teaching is mostly devoted to the establishing of a renovated Chinese soul. Apparently, the "Chinese dream" of recent years is closer to the New Confucian project, and does not envisage a Confucianisation of society, but the authoritarian appeal of Institutional Confucianism would probably gain consent within the Party.

China is looking at the economically developed states at its borders, such as Japan, Taiwan, South Korea, and so on. All these nations are examples of a combination of Western economic development, moderate freedom, traditional nationalism, traditional and modern education systems, and overall mixed societies that include both Confucian aspects (i.e. filial piety in family relations) and Westernised ways of life. China sees a Confucianisation of its internal and global identity as the chance to really become a peer with the most developed Asian countries, European countries, and the USA, rather than just the "world's low-quality factory". If "socialism with Chinese characteristics" is defined in Confucian forms, China would be able to place itself completely outside the remaining Cold War "two 
power blocks" system, which necessarily places China on the side of Russia, North Korea, and so on. This "Confucian Socialism" would allow China to create a new globalised identity, and this plan is evident if we look at the "one road, one belt" ( $y i$ lu yi dai 一路一带) project, which places China at the source of a new globalised region that covers all of the Eurasian-or even Afro-Eurasian-continent. In the enduring Russia-USA competition, Confucianism is a neutral identity that allows China to maintain a certain impartiality. Moreover, this "cultural soft power" finds a telling instance in the creation of Confucius Institutes around the world, which are warmly welcomed in impoverished departments of humanities and actually provide an extraordinary contribution to Chinese language learning and cultural knowledge, but, at the same time, are often accused of limiting research freedom in these foreign universities (Sahlins 2015). What is really interesting is that these institutes rarely organise any conferences devoted to Communist or socialist theories, but instead focus on the Chinese language and traditional culture, since this is China's new international image, as part of the new "China's charm offensive", as Kurlantzick (2007) and Hartig (2015) termed it. What China wants, is to compete not only at the economic and political levels, but also to be as culturally attractive as Japan, since China is the source of several aspects of Japanese culture that are beloved worldwide, and are the main asset of Japan's soft power (Vyas 2011, 59-62). Japan was the first Asian country to use cultural NGOs (i.e. Japan Foundations that belong to the Ministry of Foreign Affairs or Japan-China Friendship Associations) as instruments of cultural soft power (ibid., 152-9), and Confucius Institutes are evidence that China has learned from this approach. China's efforts here have been so effective that recently two American senators proposed the "Countering Information Warfare Act 2016 (S.2692)" against Chinese and Russian media (Portman and Murphy 2016), in order to control the circulation of information from these two countries thanks to worldwide channels as RT, Sputnik, PLA Daily, CCTV, and so (Chu 2016). Another instance of this "charm offensive" is the growing interest in buying European football teams and increasing investment in any kind of sport, since sport is a good way to create a new image of Chinese abroad. We should perhaps ask ourselves why Japanese or American soft power does not cause as much irritation to European countries as Chinese soft power does.

As a final instance of Xi Jinping's “Chinese dream” (zhongguo meng 中国梦) communication strategy, we want to mention the Chinese message to the world at Expo 2015 in Milan. China's Pavilion, the first one set up overseas, focused the visitors' attention on the ground floor on traditional culture (i.e. the threefold cosmology we discussed earlier), and on spectacular Yunnan rice fields created with multicoloured, tubular LED bulbs. On the first floor, there was a small theatre, where a fascinating traditional Yunnan dance was performed. Before the dance, president Xi Jinping 
welcomed visitors by presenting the brilliance of ancient China's agricultural civilisation, and the richness of the country's cuisine, as well as contemporary scientific and technological developments in food production. He closed his short speech by saying "We look forward to exchanges of agricultural expertise with all other countries to jointly ensure food security in the world and advance human civilization" (Xi 2015). The advance of human civilisation needs China, and China needs its ancient past, and only within this circular process will future progress be possible. That is the fuxing, the retrospection or return to tradition in order to have a harmonious ( he) future. After the President's welcome, the visitors could watch a nine-minute cartoon about the celebration of the New Year Lantern Festival in a traditional rural family, when the three-yes, we said three-grown up and successful children (a chemist, musician and cook) go back home and express their love for their grandparents and parents. Only the cook cannot go back home, but he greets the family thanks to a video call (see link to the video at the end of Bibliographic references). This idyllic and bucolic scene is the new image China wishes to diffuse abroad and within the country. Loving children who follow the Confucian principle of filial piety (xiao 孝), family affection as the basis for any social relationship (i.e. allocentrism), and ancient Chinese festivals, which represent a continued connection with tradition (fuxing). However, at the same time the three grown up children are modern and successful people. They represent science and technology, culture and arts, and finally the Chinese culture of the body (traditional medicine and food). According to this image, Confucian moral and cultural education is fully compatible with Westernized education and culture. It is no more the zhong ti xi yong 中体西用, since both structural ( $t i$ 体) and functional (yong 用) sides are a harmonious composition of China zhong 中 and West $x i$ 西. This cartoon testifies that Confucianism is not a temporary wave, but rather the new Chinese course, the "socialism with Chinese characteristics” (zhongguo tese shehui zhuyi 中国特色社会主义), between tradition and modernity, a path still far from complete achievement.

\section{References}

Ames, Roger. T., and Henry Rosemont H. 1998. The Analects of Confucius. New York: Ballantine Books.

Angle, Stephen C. 2012. Contemporary Confucian Political Philosophy. Cambridge: Polity Press.

Bell, Daniel A. 2010. China's New Confucianism. Politics and Everyday Life in a Changing Society. Princeton: Princeton University Press.

Billioud, Sébastien, and Joël Thoraval. 2014. Le sage et le peuple. Le renouveau confucéen en Chine. Paris: CNRS Éditions. 
Breacher, Alan. 2014. "Is the Censorship of Chinese Art Misunderstood?" Art Radar September 9, 2014. Accessed January 10, 2016. http://artradarjournal. com/2014/09/05/censorship-in-chinese-art-is-misunderstood/.

Chau, Adam Yuet. 2011. Religion in Contemporary China. Revitalization and Innovation Abingdon (Oxon): Routledge.

Chen, Duxiu. 1916. Xin qingnian 2 (4), December 1《新青年》第2卷第4号 1916年12月1日, New Youth 2 (4), 1.12.1916.

Chu, Claire. 2016. "Congress Takes on Chinese Propaganda Machine, The National Interest." Posted April 27, accessed January 10, 2017. http://nationalinterest.org/blog/the-buzz/congress-takes-chinas-propaganda-machine-15967.

Fan, Rupin. 2011. The Renaissance of Confucianism in Contemporary China. New York: Springer.

Graham, Angus Charles. 1986. Yin-Yang and the Nature of Correlative Thinking. Singapore: The Institute of East Asian philosophies.

- 1998. Disputers of the Tao. Philosophical Argument in Ancient China. Chicago and La Salle: Open Court.

$\mathrm{Gu}, \mathrm{Mu} .2000$. "Confucianism as the Essence of Chinese Tradition." In Sources of Chinese Tradition. From 1600 through the Twentieth Century, edited by Theodor de Bary and Richard Lufrano, 581-5. New York: Columbia University Press.

Hartig, Falk. 2015. Chinese Public Diplomacy: The Rise of the Confucius Institute. Abingdon (Oxon): Routledge.

$\mathrm{Hu}$, Jintao. 2011. "Hujintao zai qingzhu zhongguo gongchandang chenglì 90 zhounian dahuì shang de jianghua 胡锦涛在庆祝中国共产党成立90周年 大会上的讲话 (Hu Jintao' s speech at the 90th Anniversary of the founding of CPC)." Accessed January 10, 2017. http://cpc.people.com.cn/90nian/ GB/224164/15052968.html.

Jiang, Qing. 2011. "From Mind Confucianism to Political Confucianism." In Renaissance of Confucianism in Contemporary China, edited by Fan Rupin, 17-32. Berlin: Springer.

—. 2013. A Confucian Constitutional Order. How China's Ancient Past Can Shape Its Political Future. Princeton: Princeton University Press.

Kurlantzick, Joshua. 2007. Charm Offensive. How China's Soft Power is Transforming the World. New York: Yale University Press.

Makeham, John. 2003. New Confucianism: A Critical Examination. New York: Palgrave Macmillan.

Mou, Zongsan. 2009. Zhongguo zhexue shijiu jiang 中国哲学十九讲 (Nineteen Lectures on Chinese Philosophy). Beijing: Zhongguo banben tu guan.

Pan, Jennifer, and Yiqing Xu. 2015. "China's Ideological Spectrum.” MIT Political Science, Research Paper no. 2015-6 (version of the 17th November). 
Portman, Rob, and Chris Murphy. 2016. "Countering Information Warfare Act of 2016 March (S. 2692)." Senate of the United States. Accessed January 10, 2016. https:/www.congress.gov/bill/114th-congress/senate-bill/2692/text.

Sahlins, Marshall. 2015. Confucius Institutes: Academic Malware. Chicago: Prickly Paradigm.

Sala, I.-M. 2016. "Second 'Missing' Hong Kong Bookseller Returns from China." The Guardian, March. Accessed January 10, 2017. http://www.theguardian.com/world/2016/mar/06/second-missing-hong-kong-booksellerreturns-from-china.

Scarpari, Maurizio. 2015. Ritorno a Confucio. La Cina di oggi fra tradizione e mercato. Bologna: il Mulino.

Shi, Tianjian. 2015. The Cultural Logic of Politics in Mainland China and Taiwan. New York: Cambridge University Press.

Sun, Anna. 2013. Confucianism as a World Religion. Princeton: Princeton University Press.

Xi,Jinping. 2013a. "Right Time to Innovate and Make Dreams Come True." In The Governance of China Beijing, 2014. Beijing: Foreign Language Press co. Ltd.

—. 2013b. "Enhance China's Cultural Soft Power." In The Governance of China Beijing, 2014. Beijing: Foreign Language Press co. Ltd.

—. 2014a. "Improve Governance Capacity through the Socialist System with Chinese Characteristics." In The Governance of China Beijing, 2014. Beijing: Foreign Language Press co. Ltd.

- 2014b. "The rejuvenation of the Chinese Nation is a dream shared by all Chinese." In The Governance of China Beijing. Beijing: Foreign Language Press co. Ltd.

—. 2014c. The Governance of China Beijing. Beijing: Foreign Language Press co. Ltd.

—. 2015. "Chinese President Xi Jinping Gives Welcome Speech for the China Pavilion at Milan Expo.” Accessed January 10, 2017. http://en.expochina2015.org/2015-05/02/c_2554.htm.

Yoshiko, Ashiwa, and David L. Wank. 2009. Making Religion, Making the State. The Politics of Religion in Modern China. Stanford: Stanford University Press.

Wang, Ruichang. 2011. "The Rise of Political Confucianism in Contemporary China." In The Renaissance of Confucianism in Contemporary China, edited by Fan Rupin, 33-45. Berlin: Springer. pp.

Vyas, Utpal. 2011. Soft Power in Japan-China Relations. Abingdon (Oxon): Routledge. Zhang, Zhidong 張之洞. 1998. Quan xue pian 劝学篇 (Exhortation to Study). Beijing: Zhongzhou Ancient Books Publishing House.

“Milan shibohui zhongguo guan zhuti yingpian ‘tuanyuan'.”2015. 米兰世博会中 国馆主题影片 “团圆” “"Reunion” Short Animation at Expo 2015, Chinese Pavillon) Accessed January 10, 2017. http://www.vmovier.com/46720. 